\title{
Incaprettamento: An Unusual Homicide by Ligature Strangulation
}

\author{
Ignazio Grattagliano*, Giuseppe Troccoli, Carmen Zelano and Roberto Catanesi
}

\author{
Department of Criminology, University of Bari, Italy
}

\begin{abstract}
This case study regards the murder of a Tunisian national residing in a small town in southern Italy who was murdered by fellow Tunisian citizen, also living in Italy. The victim was found hogtied and hanged by a cord that was suspended from an iron staff situated between two concrete electrical poles. This method of killing is known as "incaprettemento". It is an unusual type of strangulation whereby a rope is passed around the victim's wrists, ankles, and throat causing suffocation. This results in a very slow and painful death. Typically, it is a method employed by Italian organized crime groups, but it has also been used in the execution of war crimes. This means of killing is meant to impart a particularly degrading and humiliating revenge on the victim. It may also serve as sign of intimidation and a warning to others. There is very little written about incaprettamento in the literature, but it has, nonetheless, important psychological, anthropological, and cultural implications in the field of criminology. The perpetrator underwent psychodiagnostic evaluations, and was ultimately deemed fit to stand trial.
\end{abstract}

Keywords: Incaprettamento, Ligature strangulation, Hog-tie, intra-ethnic homicide.

\section{INTRODUCTION}

Incaprettamento is a gruesome means of killing an individual and is most often carried out as an act of revenge. Organized crime groups, such as the Italian Mafia, use this method of killing as a punishment in response to acts of betrayal ( $\mathrm{Di}$ Maria and Lovanco,1995, Catanesi, Grattagliano,1997, De Donno et al. 2009). At times, incaprettamento is also used during wartime and may act to serve as a warning to specific ethnic and cultural groups. This method of killing involves tying a ligature around the victim's ankles and wrists behind his back, and then around his neck, ultimately constricting the jugular vein. As the victim's bent legs slowly relax, increasing tension is exerted on the cord, ultimately leading to a very slow death by strangulation. Incaprettamento is extremely rare, and very little is published in the literature on the subject (Fineschi, et al. 1998, Pollanen and Path, 2003). This case report concerns the murder of one Tunisian immigrant living in Italy by another Tunisian immigrant.

\section{THE CASE}

The case presented here involves the highly unusual method of "incaprettamento", used to carry out a homicide in a small town in southern Italy. This case came to the authors' attention following a request by judicial authorities to provide expert testimony in order to determine if the murder suspect was fully aware of his actions at the time of the crime, and if he were competent to stand trial. The subject underwent

*Address correspondence to this author at the Department of Criminology, University of Bari, Italy; Tel: +39080 5478364; Fax: +39080 5478248;

E-mail: ignazio.grattagliano@uniba.it psycho-diagnostic evaluation (Minnesota and Rorschach Tests, and Baratt Impulsiveness Scale) In addition, the investigative team carried out a complete review of the facts by examining judicial files, and police reports, etc.

The cadaver of a Tunisian man was discovered at a house on the outskirts of a small town. He was found hogtied and hanged by a cord suspended from an iron staff situated between two concrete electrical poles. Signs that the victim had been dragged were observed on the ground, and led from the inside of the dwelling to the site where the incaprettamento had been carried out. The homicide occurred following a serious argument between two Tunisian men. The perpetrator of the crime is a Tunisian citizen who was residing in Italy.

\section{2a. Characteristics of the Perpetrator}

The unmarried subject was a little over 30 years old at the time of the murder. He had earned a degree in philosophy in his native country of Tunisia, but worked as a farmhand in Italy. His father was a retired soldier, and, according to the subject, this had influenced him in his choice to join the army. His mother was a housewife, and he stated that she was "a very good mother, more open than my father, but not really much different". He described the family climate as peaceful, but also admitted that at times there were moments of conflict. He was the third of five children, and reported having good relationships with all of his siblings. In 1998 he took up a military career in the French Foreign Legion, and in 1999 he was assigned to a one-year tour of duty in the Congo. After returning to Tunisia, he requested a discharge; life as a Legionnaire did not live 
up to his expectations. Not only was his request to be discharged unsuccessful, he was sent to the Sahara Desert for a year and four months, after which time he was discharged. Over the course of his military career, he had been seen by a psychiatrist on several occasions and was prescribed anti-depressant medication for problems that were related to "nervousness". There is no other clinical history available regarding the perpetrator. Moreover, he had no prior criminal record. He moved to Italy in March 2006, attracted by better economic prospects than those available in Tunisia. He spent some time in two different cities working at various manual labor jobs including farmhand, mechanic, gas station attendant, and construction worker. He met his girlfriend, who was Polish, and they began to date, ultimately moving in together.

\section{2b. The Relationship Between Victim and Perpetrator}

The perpetrator worked in an agricultural machinery supply station and it was there where he had first met the victim, who, upon entering the establishment, recognized the perpetrator as a fellow Tunisian. According to Italian authorities, the victim had a criminal record involving robbery both in Italy and in Tunisia. Clinical records also indicated that he had a history of alcohol abuse. The two compatriots began to socialize and to spend their free time together. At times, their respective girlfriends would join them for outings in the countryside. In short, they had quickly become close friends. It was at this point in their relationship that the victim had asked the perpetrator to lend him $€ 1,500$ : which he did. Some time later, the perpetrator was convicted of committing fraud and was sentenced to two months in prison. Upon release, the subject's girlfriend informed him that his Tunisian friend had made unsuccessful sexual advances toward her. He sought out the man in order to confront him on the matter. At this time, the perpetrator demanded repayment of the $€ 1,500$ loan, but the victim refused. During an interview with a psychiatrist from the investigation team, the perpetrator later described feeling seriously betrayed by someone who he had considered to be a close friend. He expressed a desire to exact revenge on him.

\section{2c. Reconstruction of the Crime}

The perpetrator reported that he had been drinking in a bar late in the evening on the day of the murder.
As he drank, he became increasingly angrier as he pondered the betrayal he had experienced, and described leaving the bar and heading to the victim's home to try getting his money back once again. The victim refused to pay. At this point the perpetrator began to physically assault him repeatedly and dragged him outside and proceeded to tie a cord around his ankles, wrists, and neck with a clothesline cord. He suspended the victim by his neck from a cord that was tied between two concrete electrical poles, and remained there, watching the victim slowly die. The perpetrator claimed that there had not been any accomplices or help of any kind in the killing. He also denied that the murder was pre-meditated. In fact, he stated that: "if I had wanted to kill him, I would have gone there armed with a knife or something, but I was unarmed at the time. I don't know what came over me". Psychiatric evaluation demonstrated that the perpetrator was indeed fully aware of his actions and able to stand trial. In the end he was found guilty of homicide and sentenced to 30 years in prison.

\section{CONCLUSION}

In addition to the psychological aspects of this highly unusual case of homicide, there are also important anthropological and cultural ones as well. The presence of psychopathology at the time of the murder does not entirely explain the motivation for the killing, in the authors' opinion. In order to more fully comprehend why the perpetrator resorted to such an extremely cruel method of doing away with his victim, it is essential to have as deep an understanding as possible of the dynamics of their relationship.

\section{ACKNOWLEDGEMENTS}

The authors would like to thank Michael Kolk for his help in the preparation of this manuscript.

\section{REFERENCES}

Di Maria, Francesco; Lovanco, Gioacchino. 1995. Ad un passo dall'inferno, sentire mafioso ed obbedienza criminale Ed. Giunti, Firenze, Italia.

Catanesi, Roberto; Grattagliano Ignazio. 1997. Riflessioni sulla Criminalita' Organizzata in Puglia. Criminologia E Psicopatologia Forense, 1(2): pp. 43-56.

De Donno Antonio, Santoro Valeria., Rossi AnnaPaola, Grattagliano Ignazio, Introna, Francesco. 2009. Manners of Killing and Rituals in Apulian Mafia Murders. Journal Of Forensic Sciences, vol. 54, p. 895-899. http://dx.doi.org/10.1111/j.1556-4029.2009.01068.x

Fineschi, Vittorio; Dell'Erba, Alessandro; Di Paolo, Mario; Procaccianti, Paolo. 1998. Typical Homicide Ritual of the 
Italian Mafia, (Incaprettamento) The American Journal of Forensic Medicine and Pathology 19(1): pp. 87-92. http://dx.doi.org/10.1097/00000433-199803000-00017
Pollanen, Michael; Path, MRC. 2003. A variant of Incaprettamento (Ritual Ligature Strangulation) in East Timor The American Journal of Forensic Medicine and Pathology 24(1): pp. 51-54.

Received on 12-12-2012

Accepted on 30-01-2013

Published on 12-02-2013

DOI: http://dx.doi.org/10.6000/1929-4409.2013.02.2

(C) 2013 Grattagliano et al.; Licensee Lifescience Global.

This is an open access article licensed under the terms of the Creative Commons Attribution Non-Commercial License (http://creativecommons.org/licenses/by-nc/3.0/) which permits unrestricted, non-commercial use, distribution and reproduction in any medium, provided the work is properly cited. 